\title{
'Ilm Al-Bayan and Its Suitability in Analyzing Malay Poetry Texts
}

\author{
Nazri bin Atoh \\ Universiti Pendidikan Sultan Idris \\ Mohd Termizi Bin Atoh \\ SMK Pekan Kota Belud, Sabah
}

\section{Abstract}

The beauty of poetry is influenced by the choice of words expressed in the style of any languages. There are influences of Arabic language and literature in the Malay world. In addition, most of studies on Malay literature text are using western theories. Therefore, this study attempts to examine the appropriateness of the use of 'Ilm al-Bayan which is a form of Arabic Rhetoric in analyzing Malay poetry texts. The library approach is used in this study. The choice of this approach is to gather information related to IIm al-Bayan. Descriptive analysis approach is used to analyze the information gathered to see suitability of the Arabic style that used in assessing the Malay literature texts. The study found that there are similarities between the functions 'Ilm al-Bayan with Malay rhetoric, although the terms of each of these languages are different. It is certainly based on the expression of the original speakers of the language, whether in Arabic or Malay literatures.

Keywords: 'Ilm al-Bayan; aesthetic assessor, Malay poetry texts, Arabic Rhetoric

\section{Introduction}

Language plays a very important role in expressing a meaning. Accuracy in composing words can make a meaning reach the target. Therefore, the ability to recognize and master the aesthetic aspects of language can produce good work (Rahman: 1981). Thus, a poet's task in translating his ideas differs from his daily expression in terms of word choice and arrangement. This can be seen from his literary works that use beautiful words.

Dharmawijaya (1998) argues that the use of words in poetry is a deviation from the norms or norms of the language system that has been known and accepted by the 
language community itself. Among the deviations found in poetry are semantic deviations. These deviations relate to the words or vocabulary used. This is to obtain accuracy with the expression of feelings of the soul so as to give rise to a meaning that is different from the meaning in the dictionary (Dharmawijaya: 1998).

There are influences of Arabic language and literature in the Malay world. This is the effect of the arrival of Arab traders from the Arabian Gulf to China, stopping at some places such as the Malay archipelago. The Muslim Arab traders engaging with the local community led to a change in culture and religion of the Malay community to spread the religion of Islam indirectly (Rahmah \& Adli: 2008). The arrival of Islam in the archipelago region led to the knowledge of the community to the work of Arabic literature which is "shi'r". Therefore, Malay poetry is influenced by Arabic Islamic literature that revealed the literary workers based on the Malay language and genre of traditional Malay poetry such as pantun, seloka and gurindam (Rahmah \& Adli: 2008).

Based on researcher's reading, most studies on Malay Literature are using western theories. Among them are Peirce's semiotic theory in the study of Tengku Intan Marlina and Salinah (2013) and Leech's theory of meaning in the study of Md Zahril Nizam, Darwalis, Noriah and Mohd Najib (2020).

Therefore, this study attempts to examine the appropriateness of the use of 'Ilm alBayan which is a form of Arabic Rhetoric in analyzing Arabic literary texts. This is due to the influence of Arabic in Malay; such as the word absorption from Arabic. In addition, if the western theory can be used to analyze works of Malay literature, most certainly, theories from the Middle East can also be used.

The library approach is used in this study. The choice of this approach is to gather information related to 'Ilm al-Bayan. Descriptive analysis approach is used to analyze the information gathered to see suitability of the 'Ilm al-Bayan to be used in assessing the Malay literature texts.

\section{Discussion}

\section{a) 'Ilm al-Bayan}

Arabic Rhetoric or al-Balaghah al-'Arabiyyah is an interesting appearance of meaning through precise expression while giving a profound effect and in accordance with the meaning (Glosari Bahasa dan Kesusasteraan Arab: 2004). This knowledge consists of three types; namely 'Ilm al-Ma'ani,' Ilm al-Bayan and 'Ilm al-Badi'.This paper will focus the discussion in 'Ilm al-Bayan only. 
'Ilm al-Bayan is the knowledge used to keep the words used away from their vague meanings (al-Hashimiyy: 2013). al-Maraghiyy (2007) argues that 'Ilm al-Bayan is a science that explains a meaning in various forms, including different expressions in describing the semantics appropriate to the situation. The following is a diagram of the types of 'Ilm al-Bayan based on the views of al-Khatib al-Qazwiniyy (1990) and Fayyud (2004):

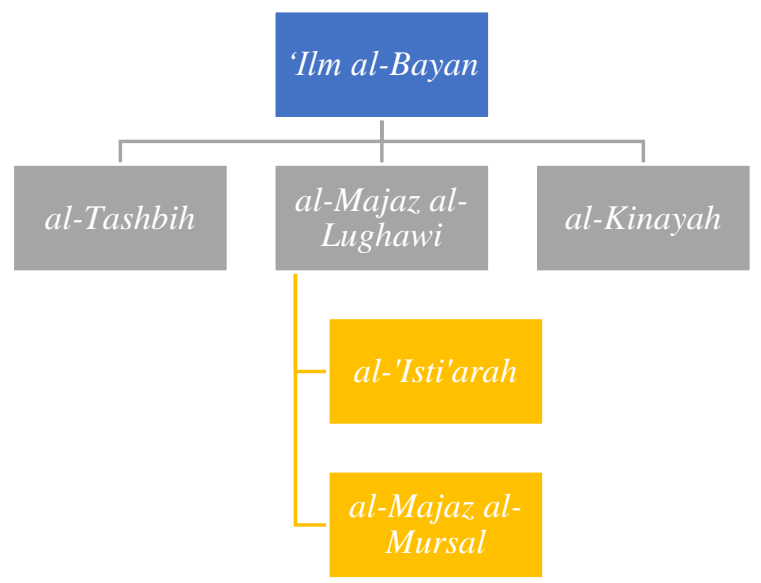

Figure 1

The types of 'Ilm al-Bayan according to al-Khatib al-Qazwiniyy and Fayyud

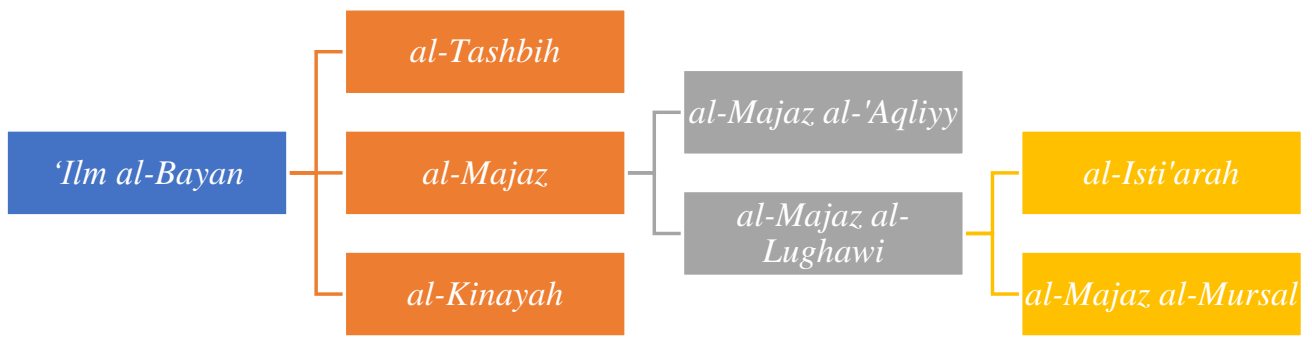

Figure 2

The types of al-Bayan according to al-Hashimiyy and 'Abbas

i. al-Tashbih

Al-Khatib al-Qazwiniy (1990) defines al-tashbih as an expression that carries the equation of one thing with another in a certain meaning. An expression is counted as al-tasbhih, if it is formed from mushabbah and mushabbah bih, which are counted as the main pillars of al-tashbih. However, al-adah and wajh al-shabah are sometimes used in this style of language. 
There many types of al-tashbih based on mushabbah, mushabbah bih, al-adah and wajh al-shabah. They are tashbih mahsus bi mahsus, tashbih ma'qul bi ma'qul, tashbih mahsus bi ma'qul, tashbih ma'qul bi mahsus, tashbih mursal, tashbih mu'akkad, tashbih mufassal, tashbih mujmal, tashbih baligh, tashbih malfuf, tashbih mafruq, tashbih taswiyah, tashbih al-jam', tashbih mufrad mutlaq bi mufrad mutlaq, tashbih mufrad muqayyad bi mufrad muqayyad, tashbih mufrad mutlaq bi mufrad muqayyad, tashbih mufrad muqayyad bi mufrad mutlaq, tashbih murakkab bi murakkab, tashbih tamthiliy and so on.

ii) al-Majaz

al-Majaz is a word that is used not in its original meaning because of the relationship with the sign that prevents it from desiring the original meaning (al-Hashimiyy: 2013). al-Majaz in 'Ilm al-Bayan is divided into two types, namely al-majaz al-'aqliy and al-majaz al-lughawiyy. Al-majaz al-lughawiyy is divided into al-isti'arah and almajaz al-mursal.

Al-Majaz al-'aqliyy is also known as al-majaz al-isnadiy and al-majaz al-hukmiy (alHarbiy: 2014). This type of language style is the reliance of verbs or on the meaning of verbs (ism fa'il, ism maf'ul or masdar) to that which is not for him in actual fact (alHashimiyy: 2013). Thus, the concept of al-majaz al-'aqliy is in the using of verbs on the non-real doer.

There are "relations" ('alaqat) in al-majaz al-'aqliy. They are used to explain the meaning in the expression, in addition there are signs that prevent to understand the real meaning. (al-Hashimiy: 2013). 'Alaqat al-majaz al-'aqliy which are widely used are like al-zamaniyyah, al-makaniyyah, al-sababiyyah, al-masdariyyah, al-fa'iliyyah and al-maf'uliyyah.

Al-Hashimiy (2013) defines al-isti'arah as the use of a word on something that is out of place for the purpose (parable) between the logical meaning and vice versa, along with cues that prevent one from desiring the original meaning. Al-Isti'arah is an expression of al-tashbih which is discarded one of its two main pillars; i.e. mushabbah or mushabbah bih. Each style of language of the form of al-isti'arah contains three pillars; al-musta'ar, al-musta'ar lah and al-musta'ar minh ('Abbas: 2000). There are many type of al-isti'arah, such as isti'arah tasrihiyyah, isti'arah makniyyah, isti'arah tahqiqiyyah, isti'arah takhyiliyyah, isti'arah asliyyah, isti'arah taba'iyyah, isti'arah wifaqiyyah, isti'arah 'inadiyyah, isti'arah 'ammiyyah, isti'arah khasiyyah, isti'arah mutlaqah, isti'arah murashshahah, isti'arah mujarradah and isti'arah tamthilyyah. 
al-Jarim and Amin (1999) say that al-majaz al-mursal is the use of a word not supporting its original meaning with a non-similar relationship along with a sign that prevents for the original meaning of the word. Since al-majaz al-mursal is formed not by similar relations, then al-Majaz al-mursal requires a factor of relations ('alaqat) in the stylistic expression. The existence of 'alaqat in an expression can distinguish its purpose formed from another.

These relationships ('alaqat) are many according to the context. al-Hashimiyy (2013) lists 'alaqat al-majaz al-mursal as al-sababiyah, al-musabbabiyah, al-kulliyah, aljuziyah, al-lazimiyyah, al-malzumiyyah, al-aliyyah, al-taqyid, al-mutlaq, al-'umum, alkhusus, i'tibar ma kan, i'tibar ma sayakun,al-haliyyah, al-mahalliyah, al-badaliyyah, almubdaliyyah, al-mujawarah and al-ta'alluq al-ishtiqaqiy.

iii) al-kinayah

Amin (2006) defines al-kinayah as a desired expression which a meaning is not the actual meaning as used, but it is still permissible to desire the original meaning because there is no sign that prevents such a desire.

This style of al-kinayah has various forms based on meaning; namely kinayah 'an sifah, kinayah' an mawsuf and kinayah 'an nisbah either in ithbat or nafiy forms. The forms of al-kinayah based on the characteristics are al-ta'rid, al-talwih, al-ramz and al-ima'.

\section{b) Malay Poetry}

Poetry is the earliest form of literature for all nations in the world because human beings in the early stages are only able to express feelings, desires, ambitions and so on in the form of speech or oral because they do not have writing (Haron: 2002). Poetry is a term used for various forms of rhythmic utterance through the full imaginative perception of a writer or poet (Glosari Istilah Kesusasteraan: 1988).

Safian et al. (Editor) (2006) in the Sejarah Kesusasteraan Melayu says that Malay poetry is a form of speaking that existed since ancient times. This kind of speech is very popular and its use is widespread among all walks of life, in line with the development of the system and thinking of the community.

Genres that belong to poetry as stated by Zalila \& Jamilah (pngr.) (1993) include pantun, syair, nazam, gurindam, seloka, teka-teki, peribahasa berirama, teromba, talibun, prosa lirik, mantera and dikir.

Abdul Halim (2006) lists the traditional Malay poetry into 18 types under three categories, namely, traditional Malay heritage poetry such as pantun, gurindam, seloka, teromba, talibun, mantera and peribahasa berangkap. The second group is the 
traditional poems of Islamic heritage such as syair, nazam, ruba'i, qit'ah, ghazal, masnawi and barzanji; while the third group is overlapping poems such as rejang, endoi, teka-teki and zikir. Za'ba (2002) lists the Sajak as a new poetic genre in the Malay literature. The following is a diagram of the types of the genre of poetry:

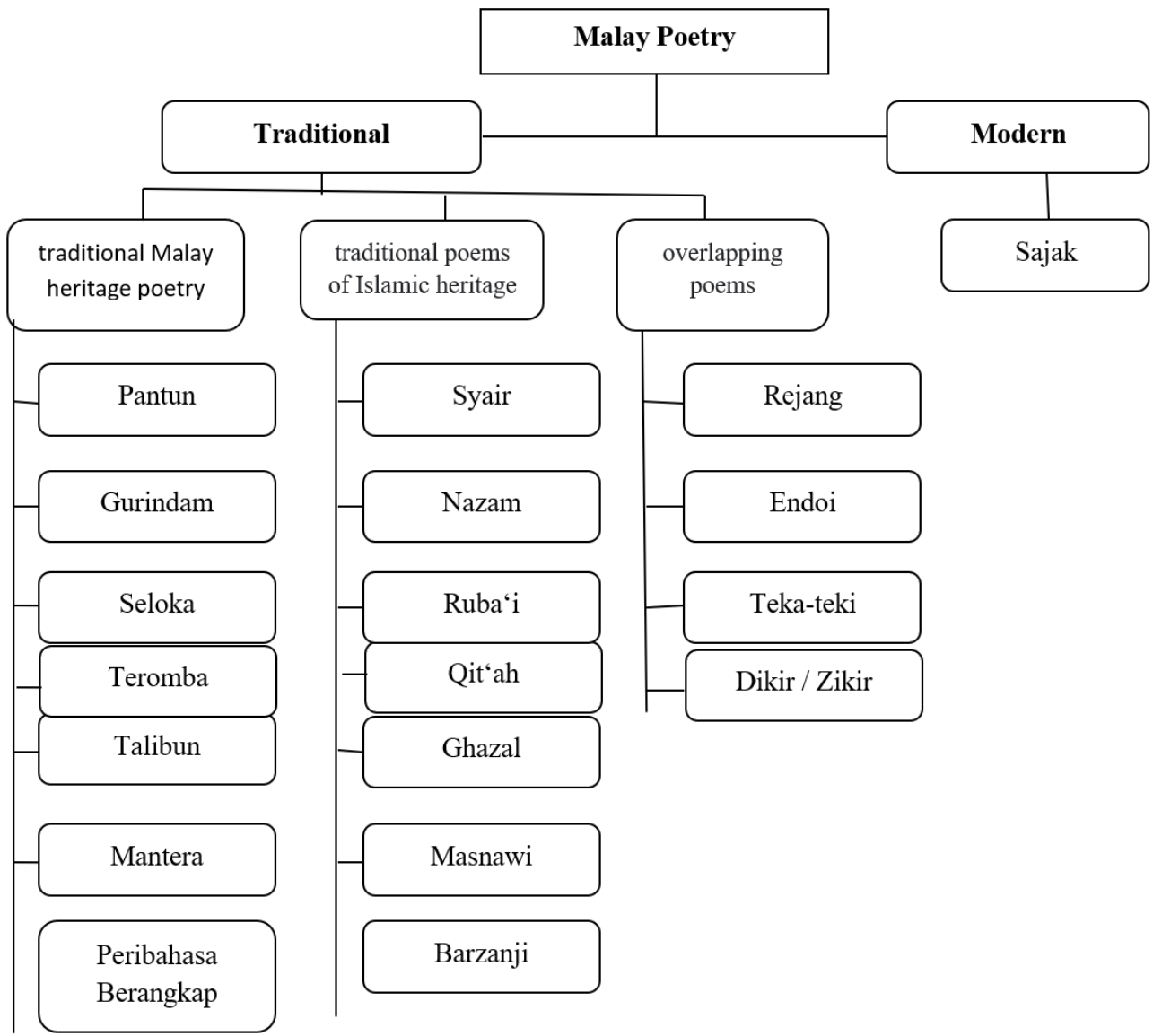

Figure 3 Genre of Malay Poetry

\section{c) The suitability of using 'IIm al-Bayan in analyzing Malay Poetry Texts.}

There are similarities in function of 'Ilm al-Bayan with Malay Rhetoric, such as tashbih mu'akkad and tashbih baligh are similar with Malay Rhetoric called metafora. This is because; these language styles are used to compare two things that have similarities without using comparisons.

Simile in Malay Rhetoric has in common with the style of tashbih mursal in "Ilm alBayan. Both are used on comparing two things by using words such as "bak", 


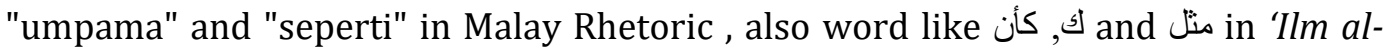
Bayan.

The similarity in functions is also shared by the isti'arah language style and the personifikasi language style. This is because both styles of languages give human nature and behavior to animals, objects or things that are abstract. hiperbola in Malay Rhetoric matches isti'arah and kinayah functions. The style of kinayah in 'Ilm al-Bayan also has similarities with the style of hiperbola with extreme use of words in meaning.

Majaz mursal in 'Ilm al-Bayan has similar functions in a style of Malay Rhetoric called sinekdoki. It is because 'alaqah majaz mursal which is al-juz'iyah expresses a part for the whole meaning.

Below is a table of similarities in function between 'Ilm al-Bayan and Malay Rhetoric:

Table 1 similarities in function between 'Ilm al-Bayan and Malay Rhetoric

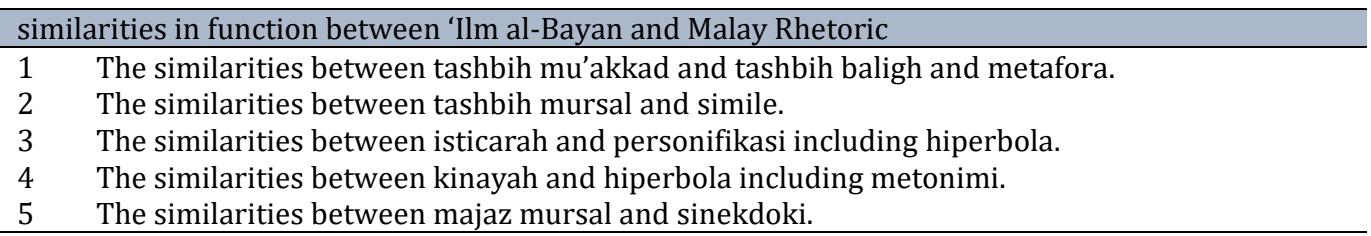

\section{Conclusion}

The use of language style in poetry is an approach in conveying a meaning to the audience in a figurative way. This is closely related to the poet's ability to use words for a meaning with beautiful expression.

There are similarities in the functions between 'Ilm al-Bayan, which is a form of Arabic Rhetoric with Malay Rhetoric, even though the terms to any style of languages are different, such as tashbih mu'akkad and tashbih baligh with metafora. The differences in terminology are certainly according to the expression of the original speakers of the style of language, whether in Arabic or Malay literatures.

\section{References}

[1] 'Abbas, F.H.. (2000). al-Balaghah fununuha wa afnanuha. 'Amman: Dar alFurqan.

[2] Abdul Halim, A. (2006). Mendekati Puisi Melayu Tradisional. Bangi: ELPOS Print.

[3] Al-Harbiy, A.A.A. (2014). Al-Balaghah al-Muyassarah. Kaherah: al-Dar al'Alamiyyah. 
[4] al-Hashimiyy, A. (2013). Jawahir al-balaghah. Beirut: Dar al-Kutub alcIlmiyyah.

[5] Al-Jarim, A. and Amin, M. (1999). Al-Balaghah al-Wadihah. Kaherah: Dar alMa'arif.

[6] al-Khatib al-Qazwini, M.A.R. (1990). al-cIdah fi culum al-balaghah. al-Sayid, Majdi Fathi (pnyt.). Kaherah: al-Maktabah al-Tawfiqiyyah.

[7] al-Maraghiyy, A.M. (2007). cUlum al-balaghah. Beirut: Dar al-Kutub alcIlmiyyah.

[8] Amat Juhari M. (2001). Nilai rasa dalam bahasa Melayu. Dlm. Yaacob, H. (pnyt.). Kosmologi Melayu, hlm. 284-298. Kuala Lumpur: Akademi Pengajian Melayu, Universiti Malaya.

[9] Amin, B.S. (2006). Al-Balaghah fi Thawbiha al-Jadid: 'Ilm al-Bayan. Beirut: Dar al-'Ilm li al-Malayin.

[10] Dharmawijaya. (1998). Dunia Puisi dalam Penelitian dan Pengajaran. Shah Alam: Penerbit Fajar Bakti Sdn. Bhd.

[11] Fayyud, B..A.F. (2004). cIlm al-bayan. Kaherah: Mu'assasah al-Mukhtar.

[12] Glosari Bahasa dan Kesusasteraan Arab. 2004. Kuala Lumpur: Dewan Bahasa dan Pustaka.

[13] Glosari Istilah Kesusasteraan. (1988). Kuala Lumpur: Dewan Bahasa dan Pustaka.

[14] Harun, J. (2002). Wacana Kesusasteraan Melayu Klasik. Tanjong Malim: Penerbit Universiti Pendidikan Sultan Idris.

[15] Md Zahril Nizam M.Y., Darwalis S., Noriah M. \& Mohd Najib A.R. (2020). Analisis Stilistik dalam Teks Melayu Hikayat Abdullah. Jurnal Melayu 19(1): 54-74

[16] Rahmah, A.O. \& Adli, Y. (2008). Al-Islam wa al-Adab al-Malayawiyy: Tahlil li Niqashat fi Maliziya. Kuala Lumpur: Universiti Islam Antarabangsa Malaysia.

[17] Rahman, S. (1981). Di Sekitar Sastera dan Kritikan. Kuala Lumpur: Utusan Publications \& Distributors Sdn. Bhd.

[18] Safian H. et.al (pngr.). (2006). Sejarah Kesusasteraan Melayu. Kuala Lumpur: Dewan Bahasa dan Pustaka.

[19] Tengku Intan Marlina, T.M.A. \& Salinah, J. (2013). Simbol Kebesaran Daulat, Mahkota dan Keris dalam Hikayat Hang Tuah. Jurnal Melayu 11:98-108.

[20] Za'ba. (2002). Ilmu Mengarang Melayu. Kuala Lumpur: Dewan Bahasa dan Pustaka.

[21] Zalila, S. \& Jamilah, H.A. (pngr.). (1993). Kesusasteraan Melayu Tradisional. Kuala Lumpur: Dewan Bahasa dan Pustaka. 